\title{
DEPARTMENTS OF THE ENVIRONMENT
}

Part II

\author{
by GEOFFREY GALLOWAY*
}

The Acts setting up the Departments of the Environment provide their offspring with the legislative tools to do the job, and to a large extent determine how effective they can become. They have all started out with a handicap. The federal Environment Canada, for example, is constrained by what the Hon. Jack Davis, Minister of the Environment, calls ". . . the extensive provincial jurisdiction in environmental and renewable resource areas". In addition to this, other departments within each government are likely to react defensively if they feel their authority threatened and very few of them can claim that their activities have no effect on the environment. For these reasons the Acts should be judged by what is left out of them as well as what they contain.

As far as tangible powers are concerned, Environment Canada has to make do with those not already wielded by the provinces. They cover coastal fisheries, migratory birds, meteorology, technical surveys, Federal Government facilities and international matters. All of these were already administered by the Federal Government before the Department was created. Some others which are listed - forests, water, wildlife - are effectively controlled by the provinces, as are inland fisheries on the prairies. New responsibilities of the Department, which make its formation more than a mere change of name, sound more hopeful than practical. For example, "the protection and enhancement of the quality of the natural environment ..."; and, "... promote and encourage the institution of practices and conduct leading to the

*1168 Spadina Crescent.

Saskatoon, Sask. better protection of environmen quality ...."In simple terms this bo down to acting as an information ce tre and giving advice on resour management. One item, howeve deserves mention, even if it is no mo than a foot in the door. This is $t$ adoption of standards of environme tal quality, for example in $t$ regulation of pollution. Once lim are established, as they routinely an for instance, by the field of food at drugs, their enforcement becomes simple matter of monitoring and leg process. At present, only gross abuse the environment stands a chance triggering government action. Clear standards are not something whi should be decided at the local level; be effective, they need to be unifor across the nation, and it is appropria that the federal Department shou shoulder the responsibility. Whether will be allowed to, however, is anoth question.

The provincial Departments hav on paper at least, much more pow than the federal one. Alberta leads th way, equipped with an Act which giv it a say in almost all decisions affectir the environment. It covers, for exan ple, "laws in force in Alberta th relate to or directly or indirectly affe the ecology of the environment ' natural resources." There are diffe ences, however, between what th Minister "may" do, what he "shall" and what the government may do c his advice. He may purchase lan promote and carry out researc projects, make plans for emergenci and issue stop orders when the Act contravened. On the other hand, I "shall" co-ordinate governmes policies, acquire information an prepare long-range plans. Finally, o his advice the Lieutenant-Governo 


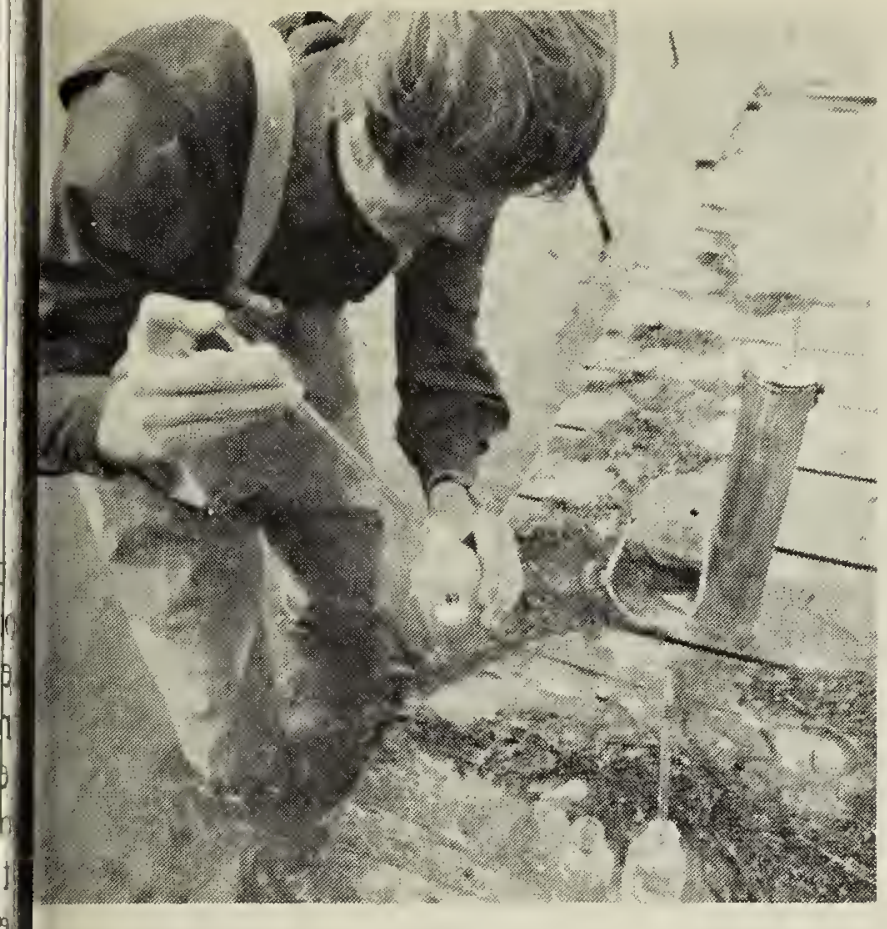

esting water quality. Sask. Photo/Arts Services

h-Council may impose curbs on other Ministers, declare a state of mergency, establish restricted evelopment areas, authorize exropriation and compensation and rescribe penalties.

Despite the wide scope of the Act, owever, the areas directly run by the Department are limited to water hanagement, control of air pollution ind agricultural chemicals. The emainder are controlled by other lepartments but it is clearly intended hat they should work in harmony with he Department of the Environment. ts Conservation and Utilization Comnittee, made up of employees from ther departments, reports directly to council of Deputy Ministers. This is wise provision, because clearly the pepartment's biggest task lies in econciling its aims with those of other ranches of government. In the conlict of conservation versus development it is likely to find itself pitted gainst formidable interests and needs o be in a position where its opinion arries weight. This it can only earn by peing better informed than its opponents and armed with alternative plans to those it is rejecting. The Act yives it the tools, but it will have to tep daintily to use them without anagonizing the rest of the government.

The Saskatchewan Act is considered ast because it is to some extent modelled on Alberta's, although more limited in scope. Passed in May, 1972, it makes the Department heir to the former Water Resources Commission, complete with its staff and premises. The Water Resources Management Act, passed at the same time, contains most of its direct responsibilities, including control of all matters concerning water works, sewage works and pollution control. Apart from these, the Minister may, as in Alberta, coordinate the policies of government agencies, undertake research, acquire information and issue stop orders. The Lieutenant-Governor-in-Council may make regulations controlling waste disposal, agricultural chemicals, gravel removal and noise levels. Notably absent, however, is any mention of acquiring land, curbing powers of other Ministers, dealing with emergencies, setting up restricted development areas, making long-term plans or economic factors such as compensation payments and cost/benefit studies. Obviously other departments have been a lot less co-operative than their counterparts in Alberta in giving up any of their power. The Interagency Co-ordinating Committee, made up of employees from other departments, reports only to the Deputy Minister of the Environment, instead of to a council of Deputy Ministers. This suggests that co-ordination does not enjoy a very high priority with the government. In short, the Department is poorly equipped for its task compared with Alberta's and will depend heavily on the pressure of public opinion to be effective.

How can public opinion be brought to bear on governments? All three Departments of the Environment have some form of advisory council which is accessible to the public, although there is a wide variation in the influence they have. The federal Act of May, 1971, contains no reference to the Environmental Advisory Council, whose membership was not announced until nearly a year later. Described as "out. side the government" in a brochure from Information Canada, it reports directly to the Minister. For this reason its influence on the Federal Government will depend, in turn, on 
the effectiveness of Environment Canada.

The Saskatchewan Act states "The Minister may, with the approval of the Lieutenant-Governor-in-Council, appoint a council to be known as the Environmental Advisory Council..." It is tempting to ask how effective the public's watchdog can be when it is appointed by the people it is watching. So far the Council's problems seem to be a limited budget and even more limited communication with the Minister. It would be premature, however, to pass judgement on the Council so early in its life.

Alberta has paid by far the most attention to its council, known as the Environment Conservation Authority. Established by its own Act in 1970, it was already in existence when the Department was formed. Of the three, it is the only council to have its functions defined by statute. As originally set up, it consisted of three salaried members appointed by, and reporting to, the Lieutenant-Governor-inCouncil. It had powers to inquire into any matter pertaining to environmental conservation, hire experts and appoint public advisory committees. All of these powers were retained when the Department was formed in 1971 but all have since been made subject to the approval of the Minister by a 1972 amendment. Recent events suggest that this approval is not easy to come b and the loss of freedom has alread caused the resignation of one of th members. The amendment also raise the number of members to four possibly in anticipation of an increase turnover. Despite all this, th Authority has packed a surprisin record of activity into its short life an is emerging as an effective spokesma for the public. During 1972 its Publi Advisory Committee passed $2:$ resolutions from four different stud groups. This makes it all the more un fortunate that its powers should have been curtailed but it is heartening to see that public pressure can have som effect, even if in this case the effect wa: a negative one.

What should we expect of an ad visory council? Perhaps the patter already exists in the field o economics. The Hon. Jack Davi described one of his Department' functions as making sure projects are well-designed from the environmenta point of view, in the same way tha other departments appraise them from the financial point of view. This invite the observation that their financia soundness is also under the scrutiny o the Auditor-General. Perhaps what is needed now is an environmental coun terpart of the Auditor-General.

Editor's Note: Manitoba information had not arrived by the time this was written in June.

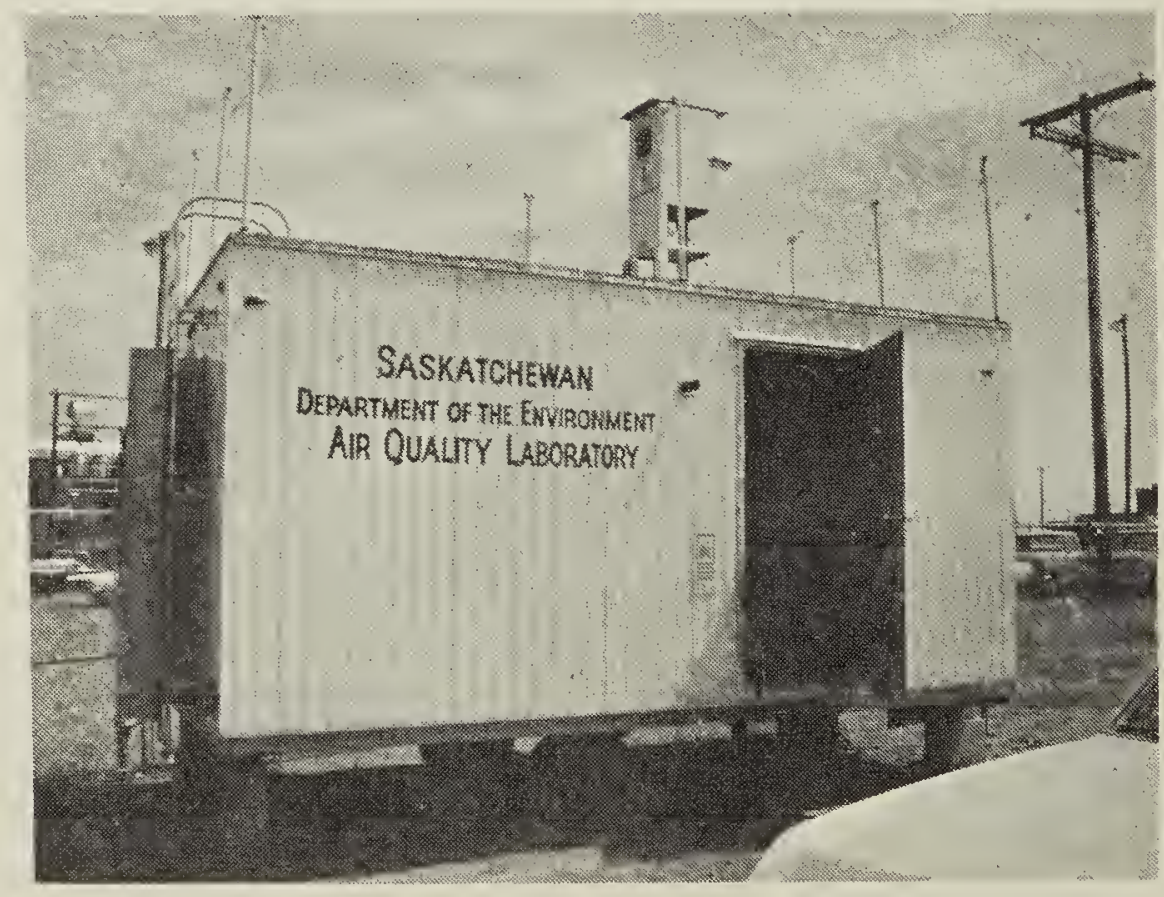

Mobile Air Quality Laboratory. Sask. Dept. Environment 